\title{
My Position Comes with Privilege: \\ I'm Going to Learn How to Use It
}

\section{Scott Richardson}

Millersville University

\begin{abstract}
This composite nonfiction narrativizes the experiences of Daniel Meyers, an assistant professor of education. Specifically, it details his transition from a graduate program to working as a full-time tenure track faculty member at a public state university. Methodologically, this research relies on parallax as an important tool to understanding Meyers's personal, intellectual, and political struggle in adjusting from a research institution to "performing" at a teaching institution. Teaching institutions, to Meyers, are significantly more customer service driven (read: making students happy) which can be problematic when faculty members have significant and different cultural understandings and interpretations than their students and the university as a whole. Meyers struggles to make adjustments, but ultimately realizes his duties as a teacher and that his contributions - though perceived alternative and conflicting with primary cultural and political narratives-provides him with an extraordinary and privileged opportunity to do important work.
\end{abstract}

Keywords: public post-secondary education, institutional politics, transitions, teacher student relationships, cultural dissonance, composite nonfiction, privilege

Scott Richardson, Assistant Professor of Educational Foundations and Women's Studies Affiliate at Millersville University.

Email: Scott.Richardson@Millersville.Edu

Brock Education, 24(1), Fall 2014, pp.26-38. 


\title{
Introduction
}

\author{
Every portrait that is painted with feeling is a portrait of the artist, not the \\ sitter. The sitter is merely an accident, the occasion.
}

- Oscar Wilde

I am sharing a story about Daniel Meyers.

I am Daniel Meyers. Believe that as much or as little as you would like. It does not matter to me one way or the other. I am unwilling to say much about the exact differences or similarities between us. I am also unwilling to parcel out the nitty-gritty details. It is partly because I really do not have a good measure of what is "true." When it comes down to it, I do not even have a reasonable or defensible understanding of who I am. However, it is also because it does not really matter. I do not mean to say that the truth has no absolute value, because I think we need to believe in it. But what the truth is, I think, is slippery and even unreal.

Recently, I explored a bunch of old film cameras with my father in his basement. We came across my grandmother's Ansco. I pressed the camera's viewfinder against my eye and noted that I could see a portion of the lens. "It's called, "parallax," my father explained. If the camera was operational, and I had taken a picture, the negative would have recorded an image different than what I saw. It would be close, but not completely accurate. This unnerved me a bit. I consider myself intentional when I produce pictures and especially when I use film. I began to wonder, "How could I be sure that the image would be accurate in other ways?" "What if the lens and the viewfinder were off-center by a simple centimeter?" This would alter the frame and composition altogether. And, "What if the images did not seem 'true'?" I illogically reasoned it "unreliable." Yet, everything is unreliable, inexact, and simply an impression. If I were to shoot a roll of film with grandma's Ansco, the moments that I lived, emotions felt, process in which I framed these phenomena would never exactly translate. If I shared the images with others, their interpretations would be different than my own and I am not so sure I could, or would, want to control that.

We are constantly engaged in wondering about the truth at all times. Therefore, I am unapologetic about putting you in this position. In fact, I think for this story the method of imposing the unknown, or disruption of research as positivism, is healthy and serves us well. Some would call my methods "fiction-based," but I am just as unsure about fiction as I am about truth. I prefer to sit on the fence; I call my work "composite non-fiction" (Sizer, 1984). I employ composite nonfiction to alter and blend details of people, places, and events in a way that allows me to write fairly and clearly (Richardson, 2012; Richardson, 2015). I write about things I know, which is different than what is true. What I know comes from the gut more than the head. The head is simply at work (un)tangling what is important to share and how. Clifford Geertz (1973) says, "man is an animal suspended in webs of significance he himself has spun...the analysis of it to be therefore not an experimental science in search of law but an interpretive one in search of meaning" (p. 4). It is my head that must honor my gut, and so when I write I ask, "How

Brock Education, 24(1), Fall 2014, pp.26-38. 
will what I know connect with the realities of others?" While this connection might help to collectively "make sense of data" to come to a mere approximation of the truth, more importantly it relies on parallax-y/our "multi-perspective as integral to the...transformative potential" (Sameshima, 2007, p. 284). In other words, it makes Daniel's and Scott's story/ies important.

\section{Daniel Meyers}

...in schools, particularly in secondary ones and those for higher learning, one observes countless persons playing at being a student, a professor, an intellectual, a radical, a bohemian, a freak, and so on, playing at being something other than themselves. They are not themselves; in Laingian terms, they are out of their minds; they are mad (Pinar, 2006, p. 11).

Daniel Meyers is an assistant professor of education at Oxbridge University (Woolf, 1928). He's completing his fifth, and possibly last, year of teaching. I met Daniel over drinks in a hotel restaurant a few years back at a conference. As everyone socialized, we shared an electrical outlet. We bellied up to the bar and stuck our noses in our laptops. We were strangers, and so we spent the first couple of hours ignoring one another, working. Then, finally, we chatted about beer.

It started by Daniel asking, "What's that you're drinking?"

"It's a Flemish red ale. It's delicious," I responded.

Daniel came off as kind, but wound tight. He seemed stressed. But to be fair, it was nearly 1 a.m., and we were both working tediously in a bar, so I suppose he might have made the same assessment of me.

We parted ways when the bar closed, but I ran into him several times over the next couple of days. Sometimes, we sat in conference sessions together, or passed one another in the hallways of the convention center. We exchanged business cards somewhere along the way, and said things like, "Yes, let's definitely stay in touch," and "I'd love to read that manuscript," because we understood conference culture. But, of course, there was no real commitment to working with one another.

The following spring I happened to be invited to give a talk at Oxbridge. When I arrived on campus, I emailed him, wondering if he was available for lunch. I had spent the winter thinking about him, and I felt odd about that. I couldn't situate my feelings, but there was something about Daniel that resonated with me.

We agreed on meeting at a small cafe in the heart of campus. I was early and he was late. I sat in a booth by the window and watched him hurriedly rush down the street, stuffing books and papers in his canvas side bag, scrambling, glancing at his watch. He looked older than I had remembered. He was disheveled. He wore jeans, a wrinkled dress shirt, a blazer, and muddy green sneakers. He burst through the door, winded.

"How are you?! Welcome! I'm so happy you're here, and I get to see you!" he said, excitedly, grabbing my hand, as though we were old friends.

Brock Education, 24(1), Fall 2014, pp.26-38. 
We settled in and talked about the campus, my lecture, and got deep into details of our work. It quickly turned into a therapy session. I lamented how much we were overworked by our respective institutions - which of course, is a trend everywhere - and he took to task the cultural and political difficulties he faced.

"I should tell you that I'm generally not a pessimistic, unnecessarily critical or paranoid kind of person."

"But you're becoming one?"

"Yes. I'm losing my mind... and my soul along the way."

"What do you mean?" I asked.

"I just don't know anything anymore. I've lost any sense of who I am. I'm a little paranoid. I'm a lot depressed. I'm just...I don't know...," Daniel paused, his eyes darted away, "I'm not me."

After an awkward silence, Daniel continued, "Truthfully? Joining academia has brought me mostly frustration and heartache. Reflecting on why this is so, I have come to two primary conclusions: 1) universities are largely not the intellectual spaces they claim to be and 2) my graduate school experience set me up for failure."

"I think I know what you mean," I said, "but, tell me more."

"Well, look at me," he said, as he glanced around the room, then whispered:

I should have the right to talk about how I feel...about my work conditions. I should feel comfortable to offer a critique so that we, the university - me included - can become more functional...supportive of students. But I'm busy looking around, wondering who might overhear me and what consequences might ensue. Non-tenured faculty are policed so heavily. Joining the faculty at Oxbridge has been nothing short of a hazing.

"That sounds exhausting."

"I bet you know what I'm talking about," he said, smiling.

"It's been tough," I admitted. "I heard, from professors in my doc program, that the university was a political machine, but I had no real idea until I landed my own job."

"Exactly!"

Daniel is a smart guy. He graduated from an Ivy League doctoral program, was nominated "doctoral student of the year," was awarded a prestigious post-doc position, and spent a year traveling, researching international education, through multiple fellowships. Prior to that, he was a middle school English teacher.

He loved being an English teacher. He was devastated when he "had to" resign because of the weight of standardization, crippling, what he called, "the capacity to do right by students." He never developed a professional life plan beyond teaching, so prior to going to graduate school he spent a year picking up odd jobs. He did some security work, fixed old cameras, and every once in a while photographed weddings and other events. All he knew was that he couldn't return to public school teaching. Daniel shared: 
The way they [administrators] required me to teach...well, anyone could do that... why would I stay in a job, committing pedagogical violence, on a daily basis, and knowing that my insight means nothing? I had nothing to develop...to work for. Toward the end of my career as an English teacher, I felt like I was just working for a pay check. Which was true. I had a young family that I needed to support. What is haunting is that I'm starting to feel the same way with this job.

"What do you mean?"

"I love the job I was hired to do at Oxbridge. I hate the job I'm expected to do. I spend more energy doing the ridiculous than working with students, writing, participating in meaningful service."

Our food came and our conversation changed to our children, but only briefly. While he talked, I had, again, the odd feeling that I understood Daniel. I had, so quickly, developed an affinity for him.

I wondered about the state of institutions. I wished my father-in-law, who attended college in the late 1960s, was sitting at the table next to us, overhearing our conversation. He romanticizes the work of the professor, probably recalling moments when faculty and students shared joints on the quad over philosophical conversations about war, communism, corporate greed, and so on. "You are so lucky," he tells me from time to time, "To work in academia... you can do that forever... what a great profession." My father-in-law remembers college as a place that was interested in social justice...a place where professors were employed to stoke the creative and intellectual capabilities of students. This was his experience. But, I wondered if universities were ever this, or if they are just less this, currently.

Regardless, at some point, university life was cast as privileged. Academics supposedly lived in ivory towers.

T. S. Eliot (1914) wrote, in a letter:

In Oxford, I have the feeling that I am not quite alive - that my body is walking about with a bit of my brain inside it, and nothing else...I hate university towns and university people, who are the same everywhere, with pregnant wives, sprawling children, many books and hideous pictures on the walls... Oxford is very pretty, but I don't like to be dead (SeymourJones, 2009, p. 1).

"My doctoral program ruined me," Daniel said, shoving a forkful of salad in his mouth, while a cherry tomato escaped and rolled around on the table leaving an oily streak of Italian dressing behind.

"How so?" I asked.

"This is turning into a rant. Is that okay?"

I shook my head and shrugged my shoulders. "Sure."

Well...graduate school gave me the opportunity to mourn properly, giving up public school teaching, by letting me intellectualize everything about my life. I "failed" at being a middle school teacher, but reasoned that it 
opened a new door so that I can make a different kind of contribution to the field of education. However, it's important to note that I never, I mean never, think the work of an education professor is more important than the work of a teacher.

"Yes," I agreed, "People have treated me so differently-with more respect since I've become a professor. I think it's absurd. We are not on the front lines."

My first semester in the doctoral program was filled with discussions about what it meant to be a professor. I remember learning that the professoriate was about living within ideas. That "the work" was to generate ideas that would lead to new inquiries and spaces that would impact the way schools might function. This was exciting. I began to feel "called" to the professorship. I could hardly wait to meet, or to construct, the future me.

"I guess this was an opportunity to reinvent yourself?"

Absolutely, but while continuing to work on the problems I faced in my public school teaching. How lucky is that?! I just needed to learn how to come at it differently... with research and new collaborations. I developed a research agenda, practiced teaching undergraduate classes, and observed professors in action. Students in my cohort would meet before and after class, over coffee or beers, and worked to challenge one another. This is how we showed our respect. I loved this life. My mentor, committee members, and others intently read in their offices and cordially argued with colleagues in hallways. I watched them conduct seminars where they shared important research that they were developing. They worked and learned alongside teachers and students in schools. In awe, I sat in small intimate classes with other students who were curious, bright, and were easily provoked by the questions our professors prepared in the margins of texts. My professors actively groomed me to understand their version of academia — which was, perhaps, a great injustice.

"Wow," I said, "that's interesting to think about...that your professors might have set you up for failure because they prepared you for the kind of academia they knew, or perhaps, the academic world they wanted."

I'll say this...my doctoral program was great for me, but it did not prepare me for the realities of the professorship - in particular, the work of a "teaching university." So, when I accepted a position at Oxbridge, which is, by the way, my undergraduate alma mater and a state school known for its teacher education program, I experienced a deep sense of shock. I was unfamiliar with the heavy and complicated burden, but important work, that informal and formal advising of students would become. My doctoral program also did not prepare me to think about how I would ultimately

Brock Education, 24(1), Fall 2014, pp.26-38. 
have to marry my scholarship and teaching if I wanted to be a semiproductive writer. There is simply no time to do both separately. I have taught, on average, thirteen courses each year since my hire. I am obligated to teach four courses in the fall and spring but find myself in the precarious situation of having to teach winter and summer courses to pay off the debt accrued while earning my doctorate. Also, students lobby me to teach these courses. They need them so that they graduate on time. I am always pressed into teaching more than necessary. Regardless, whether I am teaching eight or thirteen courses, this is a heavy load. I spend countless hours before and during the semester preparing for courses because they are so important. But I'd also like time to do things like sleep, eat a vegetable, go to the gym. Some weeks, I'm just a ghost to my family.

"I hear you. I struggle with this constantly."

My doctoral program also protected me from the drudgery of "typical" duties found at any institution-for instance, committee work. Committee work has become the bane of my existence. I value some of the work, but committees are primarily a huge time suck. In my observation, committees seem to function as a space, or an opportunity, for faculty to argue with one another over issues that just do not matter. While stuck between bickering faculties, I have come to actively daydream of a committee free university.

I laughed, hard, almost spraying my drink across the table.

But perhaps the largest shock was to confront the largely conservative, fundamentalist, Christian mentalities most of my students would bring to my classes - homophobic, xenophobic, racist, and reportedly, "against diversity." I remember the first few classes I ever taught. They were to sections of students who wanted to become elementary school teachers. White privilege was omnipresent. It was difficult for me and my few Black, Latino, and Asian students to know how to respond in productive ways to such antiquated ideas and contradictions like the belief that the U.S. is the land of opportunity for all...so in this meritocracy, anyone can "become someone"... and that "certain kinds" of people are just inherently smarter, lazier, more interested in getting an education, and generally capable. After my first full semester, my students' teaching evaluations from my Democracy and Education course-one that requires the examination of culture and schooling — anonymously read:

"Dr. Meyers talks about gay stuff too much."

"I can't help I'm white, Dr. Meyers doesn't seem to know this. He's always trying to make me feel guilty."

"He's awful. This class has no values." 
"The worst class ever. I want to know how to teach. Dr. Meyers just wanted to talk about stuff that doesn't matter. My aunt is a teacher, and she agrees with me that Black kids DO have the same opportunities, but they don't take it. Hispanic families don't try to learn English, so they are just lazy. He [Dr. Meyers] needs to get real."

like this?"

"Hold on," I interrupted, "is all of this true? Your evaluations actually said stuff

"Yes! I was devastated. I mean, I hope I stretched students in new ways, but I didn't know that I was probably just helping them to become more defensive and closeminded. And selfishly, I became concerned because evaluations like this might help to end my new career."

"That's true," I agreed:

I constantly feel awful thinking in that way. Sometimes, it is important to make students uncomfortable. To make them challenge all they know. To take risks. Often, they hate you - in the moment-for this, even though it might pay off for them in the end. Regardless, there's no professional 'pay off' as the professor. You're just doomed to poor evaluations. You don't have the luxury of measuring how students fared in the long run because of your courses. The opposite of that is just making easy and fun courses so your students like you, helping to improve your evaluations.

"Exactly. So what do we do?" Daniel asked.

"I don't know," I responded. We sat in silence, for the first time since our reunion. Using my knife, I pushed a few remaining fries around on my plate.

"So, look," he finally said, "teaching at Oxbridge just isn't what I expected. I tried to believe it was a calling, but I was fooling myself. For a moment, I thought it'd be different elsewhere. So, I interviewed other places, but they were all relatively the same."

"So you stayed."

"Yes, I stayed. Even though I was offered some great jobs, I stayed."

Over the next hour, he rattled off other lessons learned:

...Universities function like the military. Rank and file. I have come to understand that faculty members and their voices are weighed according to rank, experience and other unreasonable measures: who plays bully best, who one should not upset, which faculty members are in bed with one another (politically, religiously, and so on), or literally sleeping with one another. A very kind colleague of mine once told me, "Daniel, just keep your head down, don't say a word, and smile...just wait it out, and eventually you'll be tenured."

...Innovative pedagogical initiatives are confronted by students but are discouraged by other faculty members. I tried teaching my Democracy and Education course using a semi-open/democratic structure. Students who have been told what to do their entire lives, were disoriented... which was

Brock Education, 24(1), Fall 2014, pp.26-38. 
fine. However, my colleagues literally told them that my approach was misguided. My mentor told me, "Daniel, students are too immature to make learning decisions," and that I wasn't doing my job by offering choice. She asked me, "Why do they need you if you aren't going to tell them what to do?"

...The biggest piece of advice I've received, consistently, from my colleagues, regarding promotion and tenure is to "be visible." I see other early career faculty yucking it up with administrators, tenured faculty, and people who serve on the P\&T committee...that's just not my style. I want my good work to stand on its own. I want to be rewarded if I'm deserving. But, I'm not so sure if I will be. I've known great teachers and scholars who got denied promotion and tenure because they weren't in the cool kids' club.

... Once I was interviewed for the university newsletter. They wanted to feature me in a column called "Oxford Faculty Feature." They asked me questions about my work, thoughts about the university, and so on. I provided them with honest answers that critiqued the university's need to support our marginalized students - those who are Black, Latino, Asian, and so on. I talked about the need for an open and affirming campus climate for our queer students. I mentioned that "straight" sexual and romantic minorities, such as myself felt unwelcomed. By the way, all of these statements were connected to my research. To my surprise, the interview was never printed. Instead, they featured a faculty member who talked about his involvement in the church. I saw my interview as an opportunity to talk about my research while raising some important issues. I was disappointed to be marginalized while I spoke about marginalization.

...Most recently, I've been fighting with an office that is charging Oxbridge students a hefty fee if they take summer courses at other institutions. Can you imagine that?! Several students that I advise were complaining about it, and so I began to investigate. And it turned out true! I've done just about everything possible short of contacting local media outlets. This office threatens students, saying that the university will disallow them to transfer in credits-which is false...I called the registrar - unless they pay a fee! I've asked the administration to produce the approved policy that justifies this fee and they haven't produced one! They, however, just ask me to cooperate because it's been common practice. So, yes, Oxbridge collects money for programs and services they don't render.

My head was spinning, and Daniel began to sound like a lunatic. "Wait, wait, wait," I interrupted. "I'm sorry... but this sounds..." 
Daniel slowly put down his fork and leaned back against the large cushioned booth. His eyes went to the table and back to meet mine. He wiped his forehead with the palm of his hand. I think he felt stupid, maybe even hurt-like he should not have shared so much with a stranger. I imagined him thinking that even though he was descriptive about his experiences as a newer faculty member, detailed about the corruption at the university, and earnestly shared the cultural and political hardships he'd endured-I, just like everyone else, was just going to simplify him. I too was going to render him crazy. He dug into his bag and pulled out a printed email from an administrator and half-threw, half-dropped it in the middle of the table. It was worded cautiously but essentially warned Daniel to "back off" and to cease talking to students about their rights.

"Look," I said, "I don't mean to discredit your experiences. I'm sorry that..."

"No," he cut me off:

Maybe...well...actually, I don't really know you, but I have no reason to think you would. I just think I've been scarred and scared. As I said, I'm paranoid. I'm not who I am. I find myself thinking these past few years have traumatized me. I often feel like I'm suffering from PTSD...and then I feel guilty for even thinking that. I just never expected working at a university would be like this.

"So it's been awful. Why are you sticking around? If you are 'losing yourself,' why be at Oxbridge, or any other university?"

"Because I'm a teacher," Daniel responded. "I have to give this all I got first. And my sense is that good teaching is rarely ever about upholding the business or agenda of the institution, but rather it's about honestly considering the lives of students."

I believed Daniel's words to be true. I have thought this throughout my own public school and university teaching. In fact, I could have said these same words millions of times before. But there was something about the moment, in the way that Daniel said it, that it sounded profoundly new.

We parted ways and later in the afternoon I gave my lecture in a large room with stadium seating. I saw Daniel slip in halfway through my talk, sitting in the very last row, then leave during Q\&A. This was the last time I saw him.

When I returned home, I thought about Daniel often, particularly when I bumped up against the culture of my university, or in times that I recognized that the important and ethical road would result in more work and was politically hazardous for me. I, like Daniel, am non-tenured.

I've reasoned that Daniel and I don't hate our institutions or believe that everything that occurs is unethical. But rather, the mechanics of the institution gets in the way of learning. It forces us to perform versions of ourselves. I was prompted to email Daniel about this. I applauded him for his work and tried to sound assuring that his feeling of coming unhinged was, perhaps, good. I quoted Pinar (2012), "when we sink, submerged in those roles conceived by others, we become aborted possibilities..." (p. 40).

Months later, Daniel responded:

Brock Education, 24(1), Fall 2014, pp.26-38. 


\section{Hi Scott,}

You asked why I've stayed at Oxbridge. I said because I'm a teacher. But I didn't really know what that meant. So, I've conceptualized it. To me, I think it means that I have an obligation to learn how to do this work-the important work with students-better within this institutionalized context. But, I've come to understand that this is just as much of a journey for me. I want all of my students to experience new freedoms, to be emancipated, to be happy, to be free to take risks... That means I have to learn about how to find resilience, freedom, become emancipated, build happiness into my professional and personal life, and how to take risks. I want, with my students, to be vulnerable and interested in our holistic development. bell hooks (1994) wrote, "When education is the practice of freedom, students are not the only ones who are asked to share, to confess. Engaged pedagogy does not seek simply to empower students. Any classroom that employs a holistic model of learning will also be a place where teachers grow and are empowered in the process. That empowerment cannot happen if we refuse to be vulnerable while encouraging students to take risks. (p. 21)" Scott, I want to be boldly vulnerable. This will take a lot of work, but as I'm finally beginning to see it...it's good work. I imagine you asking something like, "What is your first step?" Well, at this moment, it's to do the three following things:

1. "Whatever your position on the food chain of American education, one of your primary obligations is to be a buffer - to absorb as much pressure as possible from those above you without passing it on to those below" (Kohn, 2001, p. 351). I'm older, wiser, and understand the politics of a university. I can see how the university unilaterally takes advantage of students. So that puts me in the position to be able to fight for them. It's my responsibility. I am actively going to be the buffer.

2. I need to be a teacher to all of my students. Those who come into my classes, and want to be educators, but are close-minded and rail against a multicultural society...well, it's my responsibility to be their teacher. I need to teach them differently. I know this sounds simple, but I've just realized that I need to meet them where they are. I can't alienate them. I need to bring them along. I can't squander the opportunity to help change their minds. It's particularly important because they will be teachers long after I'm dead and gone.

3. I'm going to continue to seek out students on my campus who have a rough go-students that were like me. I've found some already...Gabrielle, Dylan, Edwin, Bray... and we've been busy building solidarity. I've supported them as much as they've supported me. I actually feel called to be part of this group. These kids are incredibly smart. They are extraordinary thinkers. They are real people. Because 
they don't fit the landscape of my traditional university doesn't mean they don't deserve chances. We're in it together.

So, yes, I've come to understand my work at Oxbridge to be tough and complicated. And though I have felt alone and lost in the woods most of the time, I have come to recognize that my position comes with privilege. I'm going to learn how to use it.

Cheers,

Daniel

It might be cliché to suggest, but Daniel indirectly reminded me of something important - the impact of teachers, for good or bad, is truly immeasurable. Unfortunately, our standardized educational system seems to forget this. We try to quantify the work of the teacher-like with Daniel's teaching evaluations - and these kinds of institutional mechanisms do nothing but impede progress-particularly if you are interested in education as a form of freedom and emancipation. "Whoever teaches without emancipating stultifies" (Rancière, 1991, p. 18). Hopefully, Daniel has come to a new place of peace recognizing as Ayers (1993) reminds us:

Teaching is an act of hope for a better future. The rewards of teaching are neither ostentatious nor obvious - they are often internal, invisible, and of the moment. But paradoxically, they can be deeper, more lasting, and less illusory than the cut of your clothes or the size of your home... There is a particularly powerful satisfaction in caring in a time of carelessness, and of thinking for yourself in a time of thoughtlessness. The reward of teaching is knowing that your life makes a difference (p. 24).

As I've learned about Daniel's disenfranchisement, and his recent sense of privilege, he is restoring my hope.

Brock Education, 24(1), Fall 2014, pp.26-38. 


\section{References}

Ayers, W. (1993). To teach: The journey of a teacher. New York, NY: Teachers College Press.

Geertz, C. (1973). The interpretation of cultures: Selected essays. New York, NY: Perseus Books Group.

Kohn, A. (2001). Fighting the tests: A practical guide to rescuing our schools. Phi Delta Kappan, 82(5), 349-57.

Pinar, W. F. (2012). What is curriculum theory, ( $2^{\text {nd }}$ ed.). New York, NY: Routledge.

Pinar, W. F. \& Grumet, M. F. (2006). Toward a poor curriculum. Troy, NY: Educator's International Press, Inc.

Rancière, J. (1991). The ignorant schoolmaster. Redwood City, CA: Stanford University Press.

Richardson, S. (2012). EleMENtary school: (Hyper)masculinity in a feminized context. Boston, MA: Sense Publishers.

Richardson, S. (2015). Gender lessons: Patriarchy, sextyping \& schools. Boston, MA: Sense Publishers.

Sameshima, P. (2007). Seeing red: A pedagogy of parallax: An epistolary bildungsroman on artful scholarly inquiry. Buffalo, NY: Cambria Press.

Seymour-Jones, C. (2009). Painted shadow: The live of Vivienne Eliot, first wife of T. S. Eliot. New York, NY: Knopf Publishing Group.

Sizer, T. (1984). Horace's Compromise: The dilemma of the American high school. Boston, MA: Mariner Books.

Wilde, O. (1890). The picture of Dorian Gray. Lippincott's Monthly Magazine. Philadelphia, PA: J. B. Lippincott Co.

Woolf, V. (1929). A room of one's own. London, England: Hogarth Press.

Brock Education, 24(1), Fall 2014, pp.26-38. 